\title{
DEVELOPMENT STRATEGY OF SEAWEED CULTIVATION (EUCHEUMMA COTTONII) USING LONGLINEDI METHOD IN JEROWARU DISTRICT, EAST LOMBOK REGENCY, INDONESIA
}

\author{
Isnaini ${ }^{*}$, Prasetyowati Rini Endang \\ Study Program of Agribusiness, Faculty of Agriculture, Gunung Rinjani University, Indonesia \\ *E-mail: isna23031998@gmail.com
}

\begin{abstract}
The purpose of this study was to determine how the strategy for developing seaweed cultivation using the longline method in Seriwe Village, Jeorowaru District, East Lombok Regency. This research uses descriptive; the data collection technique is done by using a questionnaire. Meanwhile the determination of the research location was carried out by purposive sampling in Seriwe Vilage by taking 3 groups of seaweed cuktivaton. The data analysis technique used is descriptive, IFAS, EFAS, IE, SWOT and QSPM matrix. The results showed that the seaweed cultivation in Seriwe Village which was analyzed through the IFAS. EFAS and IE matrix illustrates that the seaweed business sis in a hold and maintain position with the cultivation business itself. However seaweed farming in Seriwe Vilage, apart from having strengths and opportunities also has weaknesses and threats that become obstacles. The following are alternative strategies that can be applied to seaweed cultivation in Seriwe Village which are analyzed using SWOT, including expanding the cultivation area, making and developing innovations from the results of seaweed cultivation, building financial institutions or cooperatives for access to capital, improving skills in cultivation techniques, utilize existing natural resources, optimize seaweed production and improve human resources by empowering group members and the community. The alternative strategy that is most interesting to implement is calculated through the QSPM matrix, namely, expanding the cultivation area with Tas 3,66 tilapia.
\end{abstract}

\section{KEY WORDS}

Development, strategy, cultivation, seaweed.

Indonesia, apart from being known as an agricultural country, is also known as a maritime country, because Indonesia is a country that consists of many islands and has very rich marine resources, one of which is seaweed. Seaweed is one of the commodities in the fisheries sector, which today is the focus of the government to make development efforts in its production section. Indonesia has several types of seaweed that can be cultivated, but there are three types of seaweed that can be cultivated, including Eucheumma cottoni, Gracillaria, and Eucheuma spinosum. Furthermore, with counseling and guidance in terms of how to cultivate it, currently there are four types of seaweed that can be cultivated in Indonesian waters including, Sargassum, Eucheuma spinosum, Eucheuma cottonii, and Glacillaria which are marketed in the form of dried seaweed. And the marketing of dried seaweed is very broad, not only in the domestic market but also in foreign markets (Nuryati, 2015).

Seaweed plants are already familiar to the community, especially those who live on the seashore. Seaweed has been used for daily life by the community both as food, medicine and beauty tools. Seaweed is a very important commodity, because seaweed plants it has a very high economic value and has great development potential in the Indonesian seas. This commodity is also starting to show its development both in terms of production and processing accompanied by support from the government regarding development in the industrial sector. This can be seen by its increasing use and not only used for food, but also used in the non-food industry (Yusri, 2016).

In Indonesia, the potential and development of seaweed is quite large. In 2014, it was recorded that the production of seaweed reached 10.2 million tons (wet), which was able to 
beat the production of other commodities, such as krapu, snapper, shrimp, carp, milkfish, tilapia, carp and catfish and with the target that Indonesia could produce dried seaweed; one million tons annually (KKP, 2014).

According to an article published by the Directorate General of Disadvantaged Regions (DITJENPDT) in 2018, that seaweed is a leading commodity in the West Nusa Tenggara (NTB) region with the potential of this province, it is not wrong if the NTB province determines seaweed as one of the commodities the production continuously increases from year to year. Almost all districts in the NTB Province produce seaweed such as Bima, Dompu, Sumbawa and West Sumbawa, East Lombok, Central Lombok, West Lombok, except North Lombok and Mataram. Seaweed can be used as a superior commodity in Indonesia. The seaweed commodity is developed evenly in Indonesian territorial waters. One of the areas that is the center of seaweed development is West Nusa Tenggara (NTB). From DKP data (2016), it was noted that seaweed production in 2015 increased by $19.6 \%$ from the previous year.

West Southeast is known as one of the seaweed producing areas. The harvest is then sold for export to China. However, there is no seaweed processing so the price obtained by the farmers has not increased. There are 10 seaweed minapolitan centers in West Nusa Tenggara, on the island of Lombok itself, including Pengantap Village, West Lombok Regency, Gerupuk Bay, Central Lombok Regency with a potential of around 200 hectares. In addition, there are also minapolitan centers (fishery-based business cities) in East Lombok Regency, including Ekas Bay with a potential of 400 hectares and Seriwe Bay with a potential of 800 hectares, and in Awang Bay with a potential of 200 hectares (Rosiady Sayuti, 2018).

Furthermore, according to Rosiady Sayuti (2018), East Lombok is a minapolitan area of seaweed plants to be precise in Ekas Bay, Seriwe Village and Awang Bay. However, based on the results of a temporary field survey that since early 2019 seaweed production in Ekas Bay has stopped due to grass production costs. sea is expensive but the selling price is low when the selling price of seaweed is also experiencing an increase and the sales chain is long. However, several villages still produce seaweed, including in Seriwe Village. The people in Seriwe Village are still producing, even most of the residents of Seriwe Village have made seaweed farming their main livelihood besides being fishermen.

Factors that can affect the level of seaweed production can come from the methods used in its cultivation, and the right cultivation techniques can potentially increase seaweed production to be efficient. The people of Seriwe Village in cultivating seaweed use the longline method. The longline method is used by farmers in Seriwe Village because it is compatible with the existing beaches in the village because this method can only be used in waters with calm currents. In addition, using the longline method does not require a large amount of money, so farmers use this method (Nirwani, 2011).

The results of the provisional survey in the field of seaweed productivity in Seriwe Village are quite large. However, the obstacles that are often faced by farmers are a lack of capital, because in Seriwe Village there are those who produce using their own capital and there are farmers who take seeds from partners. Farmers who often experience capital constraints are farmers who produce seaweed with their own capital. For that, farmers need the right strategy in developing seaweed plants using this longline method.

\section{METHODS OF RESEARCH}

The research method used is descriptive research method, which means a method for examining human groups, a scheme, objects of thought systems and classes. This research method creates a picture of an event, so this method only makes data accumulation (Nazir, 2014). This study also used data collection techniques, namely survey and interview techniques. The survey technique is a way to investigate an activity to obtain all the facts from existing symptoms and to seek factual information about the social, economic, or political institutions of a group or region. While the interview technique is the process of 
obtaining information in collecting data from respondents at the same time guided by a prepared questionnaire (Nazir, 2014).

Descriptive analysis is a method for examining the status of a group of people, an object, a set of conditions, a system of thought, or a class of events at present. This analysis has the aim of making a systematic, factual and accurate description, description or painting of facts, characteristics as well as the relationship between the phenomena studied (Nazir, 2014). Internal factor analysis is an analysis conducted to determine the strength factors used and the weakness factors that will be anticipated. Meanwhile, external factor analysis is an analysis conducted to see opportunities and avoid threats. To evaluate internal factors, the IFAS (Internal Factors Analysis Summary) matrix is used, and to evaluate external factors the EFAS (External Factors Analysis Summary) matrix is used. Determination of internal strategic factors is made first before making the IFAS matrix.

\section{RESULTS AND DISCUSSION}

Internal Factors (Strengths and Weaknesses). The method used in cultivating seaweed in Seriwe Village is more effective and efficient. Both in terms of shorter time used, less energy spent and less cost for cultivation capital, because the method used for maintenance is not complicated. The facilities and infrastructure used in seaweed cultivation are also not too difficult to find and can use existing materials. This is also one of the reasons seaweed cultivators do not pay too much.

The location of the cultivation in Seriwe Village is very appropriate and supportive because it has Seriwe Bay. In addition to supporting cultivation locations, the potential for cultivation areas in Seriwe Village is around 800 hectares (Rosiady Sayuti, 2018). The area used to cultivate seaweed is currently around more than 100 hectares for cultivation using the Longline method.

Cultivation of seaweed in Seriwe Village produces high quality seaweed because the quality of the seaweed in Seriwe Village is able to compete with seaweed in other areas and according to the community the results of production using the more methods used Most of the people in Seriwe Village work as seaweed cultivators and the human resources are very supportive of seaweed cultivation activities, and are supported by the existence of a seaweed cultivation group and also a cooperative that is specially provided for seaweed cultivators. In addition, farmers have experience in cultivating seaweed, although they are still in the moderate experience category with an average experience of 10 years.

The weakness of seaweed cultivation in Seriwe Village is that farmers are still lacking good innovation from the development of cultivation products such as food processing based on seaweed or in cultivating seaweed techniques which are still in the traditional category, so the production results can still be said to be not optimal even though for the community the production results Seaweed cultivation is quite good and the production results are more with the method used. Capital is also the most important thing in cultivating seaweed. The results of interviews with cultivators, a cooperative where special capital loans for seaweed cultivators are available in Seriwe Village, but it is still not optimal because of the slow disbursement and too many members. It can be said that $90 \%$ of seaweed farmers in Seriwe Village apply a loan system to cooperatives which is already available and collectors who provide seaweed seeds. With the system, it will be returned when they harvest by being cut from the sale according to the quantity and price of seaweed seeds.

With the existence of a seaweed cultivation group created by the community, farmers can be helped by the assistance that is distributed through the cultivation group. However, according to the group cultivators created by the community, it can be said that it is not optimal for its members. Due to the lack of empowerment activities for group members. The lack of cultivation management, especially planning management in the seaweed cultivation business in Seriwe Village, often results in high suboptimal production and low income, and even crop failure.

External Factors (Opportunities and Threats). With the supporting technology owned by seaweed cultivators in Seriwe Village, it can facilitate the community's production process. 
As already there is a canoe equipped with an engine so there is no need to pedal anymore and this makes it easier for seaweed cultivators. Government support for seaweed cultivation in Seriwe Village is quite a lot, such as socialization, there are extension workers, and also assistance that is channeled through the seaweed cultivation group. With this convenience, high public interest in cultivating seaweed in Seriwe Village. The opportunity that seaweed cultivators in Seriwe Village also have is that there are no competitors that threaten their business in the East Lombok Region so that the market opportunity for seaweed farmers is still large.

The marketing opportunity for seaweed is very large, therefore, marketing seaweed is not too difficult, because seaweed has a wide consumer, many enthusiasts and the benefits and uses of seaweed are very large, causing market demand is also high. Local investors or investors originating from Indonesia are one of the opportunities that seaweed cultivators have. However, until now, the farmers in Seriwe Village have not had any outside investors or foreign investors. Climate change is a threat from nature that cannot be avoided by seaweed cultivators. Climate change such as robe water, namely flooding caused by high tides, too strong currents and winds, and the presence of waste carried by sea water can damage seeds and disrupt the growth of seaweed.

Pests and diseases that attack seaweed can damage seaweed seeds. Like Ice-lce disease, which is a disease that arises marked by red spots then turns white which causes seaweed to become brittle and very easy to fall off and until now there is still no known cause or solution, and pests, namely attacks from fish and also moss attached. on the seedlings it causes the seeds to fall out, causing damage to the seaweed. The location of cultivation in Seriwe Village is a minapolitan area of seaweed in the East Lombok Region. However, the government is still lacking in providing the facilities needed by the community to increase the development of seaweed cultivation. Such as the unavailability of a nursery depot or warehouse and a lack of financial institutions or cooperatives. The price uncertainty is often faced by seaweed cultivators, the results of the interview the seaweed price is determined by the rise or fall of the dollar price exchange. If the dollar price rises, the seaweed price is high and vice versa. As in this pandemic season, the price of dried seaweed has decreased. From prices above 20,000 per kg to 17,000 per kg.

Business Position Based on IFAS, EFAS and IE Matrix. The results of identification of the internal factors of the seaweed cultivation in Seriwe Village are strengths and weaknesses. Furthermore, given a weight and rating for each of these factors and the total score is obtained as shown in Table 1.

Table 1 - IFAS Matrix

\begin{tabular}{|c|c|c|c|}
\hline External factors & Weight & Rating & Score \\
\hline \multicolumn{4}{|l|}{ Strength (S) } \\
\hline 1. The cultivation method used is more effective & 0,12 & 4 & 0,48 \\
\hline 2. The infrastructure used is simple and lasts longer & 0,11 & 3 & 0,33 \\
\hline 3. Great potential and supporting location & 0,13 & 4 & 0,52 \\
\hline 4. High Production and Quality & 0,12 & 3 & 0,36 \\
\hline \multirow[t]{2}{*}{ 5. Human resources support } & 0,12 & 3 & 0,36 \\
\hline & 0,60 & & 2,05 \\
\hline \multicolumn{4}{|l|}{ Weakness (W) } \\
\hline 1. Farmers are still lacking in innovation & 0,11 & 2 & 0,22 \\
\hline 2. Lack of capital & 0,10 & 2 & 0,20 \\
\hline 3. The cultivation group is not optimal & 0,09 & 1 & 0,09 \\
\hline 4. Lack of Cultivation Management & 0,10 & 2 & 0,20 \\
\hline Total & 0,40 & & 0,71 \\
\hline Total Internal Factors & 1,00 & & 2,76 \\
\hline
\end{tabular}

Source: Primary Data Processed, 2020.

Based on Table 1, the calculation of internal strategy factor analysis produces the greatest strength of seaweed cultivation in Seriwe Village, namely, the potential for large and supportive cultivation sites, with a score of 0.52 . Meanwhile, the main weakness of 
cultivators is still lack of innovation with a score of 0.22 . The total score of the internal strategy factor is 2.76 .

The results of identification of the external factors of seaweed cultivation in Seiwe Village are opportunities and threats. Furthermore, given a weight and rating for each of these factors and the total score is obtained as shown in the EFAS matrix in Table 2.

Table 2 - EFAS Matrix

\begin{tabular}{|c|c|c|c|}
\hline External Factors & Weight & Rating & Score \\
\hline \multicolumn{4}{|l|}{ Opportunity (O) } \\
\hline 1. Supporting technology & 0,11 & 3 & 0,33 \\
\hline 2. Government support and community interest & 0,13 & 4 & 0,52 \\
\hline 3. Lack of competitors & 0,12 & 3 & 0,36 \\
\hline 4. Easy marketing & 0,10 & 3 & 0,30 \\
\hline 5. Local investor support & 0,12 & 3 & 0,36 \\
\hline Total & 0,58 & & 1,87 \\
\hline \multicolumn{4}{|l|}{ Threat (T) } \\
\hline 1. Climate change & 0,12 & 2 & 0,24 \\
\hline 2. Pests and diseases & 0,09 & 1 & 0,09 \\
\hline 3. The government has not been optimal in facilitating seaweed cultivators & 0,11 & 2 & 0,22 \\
\hline 4. Price Flux & 0,10 & 1 & 0,10 \\
\hline Total & 0,42 & & 0,65 \\
\hline Total External Factors & 1,00 & & 2.52 \\
\hline
\end{tabular}

Source: Primary Data Processed, 2020.

Based on the results in Table 2, from the calculation of external strategic factors, the greatest opportunity is, government support and high public interest with a score of 0.52 , while the main threat is climate change with a score of 0.24 . The total score on the external strategy factor is 2.52 .

Table 3 - Total Score of IFAS and EFAS Matrix in IE Matrix

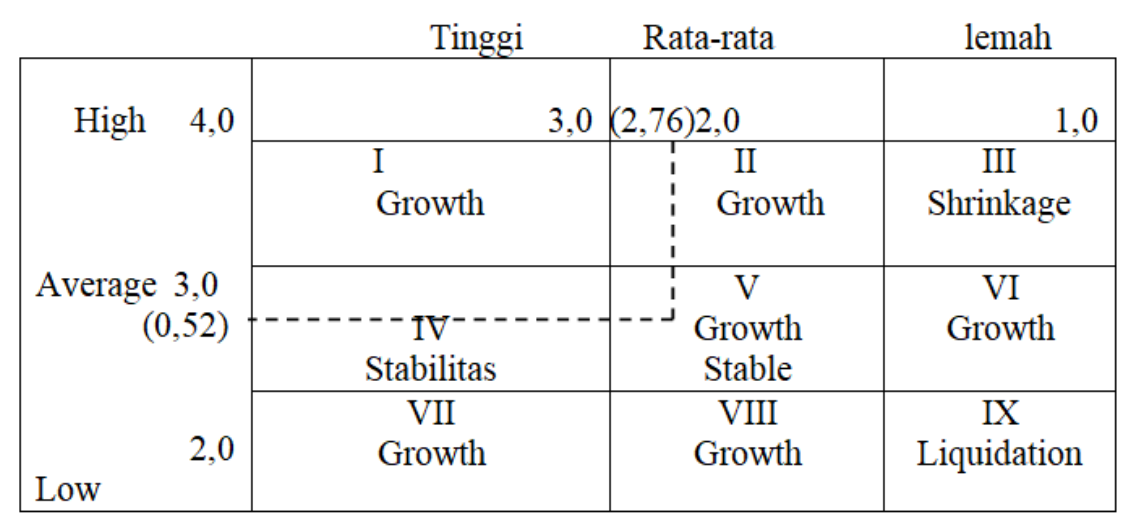

Source: Primary data processed, 2020.

Based on Table 3, the position of the seaweed cultivation business in Seriwe Village is in cell V, it is obtained that the growth strategy is carried out by maintaining and maintaining (hold and maintain). Strategies that can be applied are product development into products that have added value such as making various foods from dried seaweed by processing them into various products such as dodol, crackers, agar-based seaweed and developing marketing by expanding new locations and customers.

SWOT matrix is made based on strategic factors, both internal and external, consisting of Strengths, Weaknesses, Opportunities and Threats. The strategy formulation in the SWOT matrix has been adjusted to the results obtained from the evaluation of internal and external factors to find alternative strategies for seaweed cultivation in Seriwe Village. The results of the SWOT analysis calculation can be seen in Table 4. 
Table 4 - SWOT Matrix of Seaweed Cultivation in Seriwe Village, Jerowaru District

\begin{tabular}{|c|c|c|}
\hline EXTERNAL & $\begin{array}{l}\text { Strength (Strength) } \\
\text { 1. The method used is effective and } \\
\text { efficient } \\
\text { 2. Infrastructure is simple and lasts } \\
\text { longer } \\
\text { 3. Location of cultivation supports and } \\
\text { great potential } \\
\text { 4. High Production and Quality } \\
\text { 5. Human Resources Support }\end{array}$ & $\begin{array}{l}\text { Weakness } \\
\text { 1. Lack of Cultivator Innovation } \\
\text { 2. Lack of Capital } \\
\text { 3. The Budidya Group is still not } \\
\text { optimal. } \\
\text { 4. Lack of Cultivation Management }\end{array}$ \\
\hline $\begin{array}{l}\text { Opportunities } \\
\text { 1. There is Supporting } \\
\text { Technology } \\
\text { 2. Government Support and } \\
\text { Public Interest } \\
\text { 3. Lack of Competitors } \\
\text { 4. Easy Marketing } \\
\text { 5. Local Investor Support }\end{array}$ & $\begin{array}{l}\text { S-O strategy } \\
\text { 1. Expanding the area of seaweed } \\
\text { cultivation (S1, S2, S3, S5, O1, O2, } \\
\text { O3, O4, O5) } \\
\text { 2. Creating and developing } \\
\text { innovations for the cultivation of } \\
\text { seaweed (S4, S5, O2, O3, O4) }\end{array}$ & $\begin{array}{l}\text { W-O strategy } \\
\text { 1. Improve skills in cultivation } \\
\text { techniques (W1, W3, W4, O1, O2) } \\
\text { 2. Optimizing financial institutions / } \\
\text { cooperatives for access to capital (W2, } \\
\text { W3. O2, O3, O4, O5) }\end{array}$ \\
\hline $\begin{array}{l}\text { Threats } \\
\text { 1. Climate Change } \\
\text { 2. Pests and Diseases } \\
\text { 3. The government has not } \\
\text { been optimal in providing } \\
\text { facilities. } \\
\text { 4. Price Fluctuation }\end{array}$ & $\begin{array}{l}\text { S-T strategy } \\
\text { 1. Make use of natural resources that } \\
\text { are around (S2, S3, S5, T3) } \\
\text { 2. Optimizing seaweed production (S1, } \\
\mathrm{S} 4, \mathrm{~S} 5, \mathrm{~T} 1, \mathrm{~T} 2)\end{array}$ & $\begin{array}{l}\text { W-T strategy } \\
\text { 1. Improve human resources by } \\
\text { empowering members of cultivation } \\
\text { groups (W1, W2, W3, T2 }\end{array}$ \\
\hline
\end{tabular}

Source: Primary data processed, 2020.

The results of the analysis of internal and external factors (IFAS and EFAS) show that the SWOT matrix analysis regarding the strategy for developing seaweed cultivation using the longline method in Seriwe Village produces 4 possible sets of alternative strategies, which are as follows. Expanding the area of seaweed cultivation using the longline method. The combination of the power variables $\mathrm{S} 1, \mathrm{~S} 2, \mathrm{~S} 3, \mathrm{~S} 5$ with the probability variables $\mathrm{O} 1, \mathrm{O} 2$, O3, O4, O5. The cultivation method used is effective and efficient, the facilities and infrastructure are easy for human resources to support and Seriwe Village has a potential cultivation area of 800 hectares for the development of seaweed cultivation. More than 200 hectares of land will still be used either by raft, longline or basic stakes. Cultivation using the longline method alone only uses more than 100 hectares. In addition, with the existence of technology that supports cultivation activities, government support, lack of competitors and easy marketing with high demand because many industries are made from seaweed for food, health and beauty. For this reason, it is necessary to expand the area of seaweed cultivation using the longline method while maintaining and maintaining cultivation, according to the results in the IE matrix.

Creating and developing innovations for the cultivation of seaweed. The combination of strength variables S4, S5 with opportunity variables $\mathrm{O} 2, \mathrm{O} 3, \mathrm{O} 4$ Strengths, among others, support human resources and cultivation experience as well as production and high quality of the need to make innovations or make food product development from seaweed, so that seaweed products are usually only sold dried can be processed into various kinds of preparations to increase the selling value of seaweed. Meanwhile, the opportunities, government support and high public interest, lack of competitors and easy marketing both in terms of production and innovation of aquaculture products, provide great opportunities for developing seaweed products. This is related to the choice of strategy in the IE matrix, namely for product development.

Improve skills in cultivation techniques. The combination of the weakness variables W1, W3, W4 with the probability variables O1, O2. This strategy has the weaknesses of a lack of innovation and suboptimal cultivation groups, which means that there is no development or innovation in terms of cultivation techniques. While the opportunities are, there is supporting technology and government support as well as public interest which allows for activities or training to make cultivation methods used even better. 
The combination of the variables $\mathrm{W} 2, \mathrm{~W} 3$ with the probability variables $\mathrm{O} 2,03, \mathrm{O} 4, \mathrm{O} 5$. This strategy has a weakness in terms of a lack of capital which makes the cultivation group and the community not optimal in cultivating seaweed. While the opportunities are government support and public interest and lack of competition and easy marketing. Based on this aspect, optimizing financial institutions or cooperatives by improving services and adding cooperatives and financial institutions will greatly assist cultivators in running the seaweed cultivation business.

Make use of natural resources that are around. The combination of strength variables S2, S3, S5 with the threat variable T3. This strategy has strengths, simple and durable infrastructure for the cultivation method used, the location that supports it and the potential is still large and the human resources support it. Meanwhile, the threat is that the government does not facilitate the cultivators in their cultivation activities, especially the depot / warehouse for seaweed nurseries which are needed by the people of Seriwe Village. With the strength and threat, the cultivators as much as possible take advantage of the natural resources that are around them, such as conducting nurseries in the cultivation area using the raft method.

The combination of the strength variables $S 1, S 4, S 5$ with the threat variables T1, T2. This strategy has the strength of the methods used effectively and efficiently, production and high quality and supporting human resources. With the strengths and threats they have, it allows farmers to optimize the capacity (carrying capacity) of the amount of seaweed that will be produced by maximizing production with the available production capabilities and facilities and also increasing the quality of production both from cleanliness and maintenance, and selecting the right location in order to minimize pest and disease attacks.

The combination of the weakness variables $\mathrm{W} 1, \mathrm{~W} 3, \mathrm{~W} 4$ with the threat variable T2. This strategy is used because of its weaknesses. Cultivators lack innovation and cultivation groups are less than optimal. While the threats are pests and diseases that interfere with seaweed. Based on these aspects, to reduce risks due to threats, it is necessary to increase human resources by empowering group members and the community so that before the community carries out cultivation activities they can make good cultivation management first to reduce the risk of threats.

Based on the results of the calculation of internal and external factor scores and the results in the SWOT quadrant, it can be seen that currently the seaweed cultivation area in Seriwe Village is at the coordinate point which is located at point $x=0.67$ and $y=0.61$, which is in Quadrant I Progressive Quadrant / aggressive. The general strategy that can be carried out in this position is to provide support for aggressive growth policies for cultivation by using the strengths and opportunities that are owned for the development of seaweed cultivation in Seriwe Village, Jerowaru District, East Lombok Regency.

The results of the calculation of the QSPM matrix, obtained the most interesting alternative strategies to be implemented and prioritized by seaweed cultivators in Seriwe Village, namely, expanding the cultivation area with a TAS value of 3.66 , the reason is according to Rosiady Sayuti (2018) as Secretary of the Nusa Landmarks Region In the West, Seriwe Village has 800 hectares of potential as a seaweed cultivation area or area, but until now farmers only use about 264 hectares in 2019.

\section{CONCLUSION}

Based on the research results, it can be concluded that from the results of the SWOT Quadrant Diagrama, the coordinate point of the total score of each factor is ( $X=0.67$, $Y=O, 61$ ) which means that the Seaweed Cultivation Area in Seriwe Village is in Quadrant I, namely The Progressive Quadrant, a general strategy that can be implemented in this position is to take advantage of the strengths and opportunities they have for the development of seaweed cultivation in Seriwe Village, Jerowaru District, East Lombok Regency.

The results of the SWOT matrix calculation resulted in 7 alternative strategies for the development of seaweed cultivation using the Longline method in Jerowaru District, East 
Lombok Regency, including: (1) Expanding the area of seaweed cultivation, (2) Creating and developing innovations from seaweed cultivation, (3) Increasing Skills in cultivation techniques, (4) Optimizing financial institutions / cooperatives for access to capital, (5) Utilizing existing natural resources around them, (6) Optimizing seaweed production, and (7) Improving human resources by empowering members of cultivation groups.

\section{ACKNOWLEDGEMENTS}

The authors express deepest gratitude to PT. Indofood Sukses Makmur Tbk for research funding assistance provided through the 2020-2021 Indofood Research Nugraha (IRN) program, and to the supervisors and examiners who have assisted and directed the authors in completing the final project.

\section{REFERENCES}

1. (Anonim), 2018. Pemprov NTB Genjot Produksi Rumpu Laut. Duta Selaparang. https://dutaselaparang.com diakses pada tanggal 27 Februari 2010 pukul 22.32 WITA.

2. Adisti,S (2017). Memanfaatkan Usia Produktif Dengan Usaha Kreatif Industri Pembuata Kaos Pada Remaja Di Geresik. Universitas Negeri Surabaya. Surabaya. http://media.neliti.com diases pada 31 Juli 2020 pukul 15:42 WITA.

3. Agustina, S. 2011. Ilmu Usaha Tani. Universitas Brawijaya Press. Malang. http://eprints.stiperdhrmawacana.ac.id diakses pada tanggal 07 Agustus 2020.

4. Anggadireja. 2011. Kajian Strategi Pengembangan Industri Rumput Laut and Pemanfaatanya Secara Berkelanjutan, BPPT. Dalam Salim, Zamroni and Ernawati, 2015. "Info Komoditi Rumput Laut".

5. Angrand, La Ode. 2019. Analisis Pengembangan Budidaya Rumput Laut Dengan Metode Long Line Di Kecamatan Poso Pesisir Kabupaten Poso Provinsi Sulawesi Tengah. Universitas Terbuka Jakarta. http://repository.ut.ac.id

6. Ayu Natih Widhiarini, N. M. 2018. Strategi Pengembangan Kawasan Budidaya Rumput Laut Sebagai Wisata Konservasi and Edukasi Berbasis Masyarakat Di Pantai Pandawa. Karya Tulis. Sekolah Tinggi Pariwisata Bali Internasional Denpasar.

7. Badan Pusat Statistik, 2019. Kecamatan Jerowaru Dalam Angka. Kabupaten Lombok Timur.

8. Basit, A. 2019. Strategi Pengembangan Agribisnis Semangka Di Kecamatan Praya Timur. Skripsi. Universitas Gunung Rinjani.

9. Dewi, Indah Novita, 2018. Karakteristik Petani and Kontribusi Hutan Kemasyarakatan (Hkm) Terhadap Pendapatan Petani di Kulon Progo. Universitas Gajah Mada. Yogyakarta. http://journal.ugm.ac.id diakses pada 30 juli 2020 pukul 22:00 WITA.

10. Diat Prasojo, L. (2018). Manajemen Strategi. UNY Press. Yogyakarta. http://staffnew.uny.ac.id diakses pada tanggal 07 Agustus 2020.

11. Fidyansari, D, 2015. Strategi Peningkatan Produktivitas Rumput Laut di Daerah Pesisir Pantai Kelurahan Songka Kecamatan Wara Selatan Kota Palopo.https://journal.uncp.ac.id diakses pada 13 Februari 2020 pukul 11:46 WITA.

12. Karmini, 2018. "Ekonomi Produksi Pertanian". Mulwarman University Press. Samarin.

13. KKP.2014. Profil Peluang Usaha and Investasi Rumput Laut Edisi ke-4. DalamSalim, Zamroni and Ernawati, 2015. "Info Komoditi Rumput Laut".

14. Manyamsari, I and Mujburrahmad, 2014. Karateristik Petani and Hubungannya dengan Kompetensi Petani Lahan Sempit (Kasus: Di Desa Sinar Sari). https://media.neliti.com

15. Nazir, Moh. 2014."Metode Penelitian". Bogor : Gahalia Indonesia.

16. Nirwani, S. 2011. Aplikasi Budidaya Rumput Laut Eucheumma cottonii (Weber van Bosse) Dengan Metode Jaring Lepas Dasar (Net Bag) Model Cidaun. http://ejournal.undip.ac.id/index.php/bulomadiakses pada 20 Desember pukul 19.40 WITA.

17. Nuryati, Yati. 2015. Perdagangan Dalam Negeri Rumput Laut. Dalam Salim, Zamroni and Ernawati, 2015. "Info Komodit Rumput Laut". 
18. Priono, Bambang, 2013. Budidaya Rumput Laut Dalam Peningkatan Industrialisasi. http://ejournal-balitbang.kkp.g0.id diakses pada tanggal 2 Januari 2020 pukul 13:51 WITA.

19. Rahim, Abd and Hastusti, Diah Retno Dwi. 2005. "Sistem Manajemen Agribisnis". Cet-1 Makassar: State University of Makassar Press, 2005.

20. Rangkuti, F. 2017. Analisis SWOT Teknik Membedah Kasus Bisnis. Penerbit: PT Gramedia Pustaka Utama. Jakarta, 2008.

21. Saeri, Moh. 2018. "Usahatani and Analisisnya". Penerbit: Universitas Wisnuwardhana Malang Press (Unidha Press).

22. Salim, Zamroni and Ernawati, 2015. "Info Komodit Rumput Laut". Badan Pengkajian and Pengembangan Kebijakan Perdagangan Al Mawardi Prima, Jakarta 2015.

23. Sayuti, Rosiady, 2018. Lombok Timur, Kawasan Minapolitan Rumput Laut. DITJENPDT.Kemendesa.https://ditjenpdt.kemend esa.go.id diakses pada tanggal 25 Februari 2020 pukul 15.25 WITA.

24. Siagian, Sondang. P. 2007. "Manajemen Strategi'. Jakarta: PT Bumi Aksara.

25. Sugiyono. 2014. "Metodologi Penelitian". Bandung: Alfabeta.

26. Suroso, 2006. Analisis Curah Hujan Untuk Membuat Kurva Intensity Duration Frquenency (IDF) Dikawasan Rawan Banjir Kabupaten Banyumas. Universitas Brawijaya Malang. http://sipil-uph.tripod.com diakses pada tanggal 12 Agustus 2020.

27. Susilowati, Sri Hery, 2016. Fenomena Penuaan Petani and Berkurangnya Tenaga Kerja Muda Serta Implikasinya Bagi Kebijakan Pembangunan Pertanian. Pusat Sosial Ekonomi and Kebijakan Pertanian. Jawa Barat. http://ejurnal.litbang.pertanian.go.id diakses pada 30 Juli 2020 pukul 21:49 WITA.

28. Swarsono, M. 2008. "Manajemen Strategi (Konsep and Bisnis)". Penerbit: Sekolah Tinggi IImu Manajemen YKPN. Yogyakarta, 2008.

29. Taufiqurakhman, 2016. Mengenal Manajemen Startegi. Fakultas IImu Sosial and IImu Politik. Jakarta. http://moestopo.ac.id diakses pada tanggal 08 Agustus 2020.

30. Ulfatur, Rahmah. 2019. Analisis Potensi and Strategi Pengembangan Budidaya Rumput Laut di Kecamatan Bluto Kabupaten Sumenep. Skripsi. UIN Syarif Hidayatullah Jakarta.

31. Wahyuaji, A, 2016. Strategi Pengembangan Usaha Hasil Olahan Carica. Universitas Islam Negeri Syarif Hidayatullah. Jakarta.

32. WWF. 2014. Seri Panduan Perikanana Skala Kecil Budidaya Rumput Laut. Dalam Salim, Zamroni and Ernawati, 2015. "Info Komodit Rumput Laut".

33. Yusri, R Muh. 2016. Analisis Faktor-Faktor Yang Mempengaruhi Peningkatan Pendapatan Petani Rumput Laut Di Desa Laikang Kecamatan Mangkarombang Kabupaten Takalar.Skripsi.UIN Alauddin Makassar. 